American Journal of Applied Sciences 7 (7): 922-928, 2010

ISSN 1546-9239

(C) 2010 Science Publications

\title{
Hydrocarbon Biodegrading Potentials of a Proteus vulgaris Strain Isolated from Fish Samples
}

\author{
${ }^{1}$ Patience O. Olajide and ${ }^{2}$ L.B. Ogbeifun \\ ${ }^{1}$ Department of Microbiology, Obafemi Awolowo University, lle-lfe, Nigeria \\ ${ }^{2}$ Department of Human Resources, Nigerian National Petroleum Corporation Towers, \\ Herbert Macaulay Way, Central Area, Garki Abuja, Nigeria
}

\begin{abstract}
A Proteus vulgaris bacterium SR-1 was isolated from a freshly killed fish sample collected close to the point of crude oil spill in the Niger Delta region, Nigeria. Problem statement: The application of native bacterial species in bioremediation processes has long been desired, because they would be cost effective and efficient in terms of acclimation time. The ability to isolate high numbers of certain oil-degrading microorganisms from oil-polluted environment is evidence that these microorganisms are the active degraders of that environment. In this study, we reported the potential of a candidate bacterium- Proteus vulgaris SR-1 in the biodegradation of Bonny light crude oil, diesel and kerosene. Approach: To screen for oil degrading capability, the bacterium was cultivated in Minimal Salts Medium (MSM) supplemented with $1 \%$ (v/v) sterile Bonny Light Crude Oil (BLCO). Oil degradation was monitored by measurement of turbidity using a spectrophotometer and the $\mathrm{pH}$, total viable counts of the culture fluids were determined at time intervals as biodegradation indices. The ability of strain to degrade diesel and kerosene oils was also studied while the level of used hydrocarbon degradation was determined using the gravimetric analysis. The bacterium was screened for presence of Plasmid DNA and implication of plasmid in hydrocarbon degradation was investigated. Results: (1) The bacterium utilize hydrocarbons as sole source of carbon and it biodegraded Bonny light crude oil, kerosene and diesel media by as much as 78,79 and $73.8 \%$ respectively, in the presence of $1.0 \% \mathrm{NaCl}(\mathrm{w} / \mathrm{v})$ after $96 \mathrm{~h}$. The total viable count after 96,120 and $168 \mathrm{~h}$ of biodegradation of the test hydrocarbons range between 6.2 and $9.1 \log _{10}$ c.f.u mL ${ }^{-1}$, (2) The results showed that increasing $\mathrm{NaCl}$ concentration in water had decreasing effect on hydrocarbon degradation. (3) $\mathrm{pH}$ of media decreased from 7.0 to between 3.29 and 5.02 during the reaction period while growth increases. (4) Plasmid analysis revealed the presence of a plasmid of approximately $9.1 \mathrm{~kb}$ in the bacterial isolate. Conclusion/Recommendations: The results of this study showed that Proteus vulgaris SR-1 is a highly adapted bacterium with great potential to biodegrade hydrocarbons and the genes responsible for hydrocarbons biodegradation could be located on the $(9.1 \mathrm{~kb})$ plasmid it harbors.
\end{abstract}

Key words: Niger delta, bacteria, hydrocarbons, biodegradation, Plasmid

\section{INTRODUCTION}

In Nigeria, the scourge of environmental pollution has reached a frightening scale in recent years especially in the Niger-Delta region, the largest delta in Africa and the third largest in the world where most of the crude oil in the country is found (HRW, 1999). This region encompasses an area of approximately $70,000 \mathrm{~km}^{2}$ accounting for about $7.5 \%$ of the country's total land mass, covering a coastline of $560 \mathrm{~km}$, about two-third of the country's entire coastline. In the Niger Delta, increasing petroleum exploration and transportation has introduced large amounts of hydrocarbons into the area (Odokuma and Dickson, 2003a; 2003b).

Accidental and deliberate crude oil spills have been and still continue to be, a significant source of environmental pollution and poses a serious environmental problem, due to the possibility of air, water and soil contamination (Trindade et al., 2005). According to Fasasi (2006), oil spill also destroys the biodiversity of the delicate ecosystem of the Niger Delta. The processes leading to the eventual removal of hydrocarbon pollutants from the environment has been extensively documented and involves the trio of physical, chemical and biological alternatives (Okoh, 2006).

Corresponding Author: Patience O. Olajide, Department of Microbiology, Obafemi Awolowo University, lle-lfe, Nigeria 
Many bacteria and fungi have demonstrated potentials in the biodegradation of hydrocarbon pollution and these organisms are widely distributed in marine, freshwater and soil habitats (Head and Swannell, 1999). The biodegradation of crude oil by microorganisms is one of the primary ways for eliminating crude oil from contaminated sites and appears to be the most environmentally friendly method of removal of oil pollutant (Barathi and Vasudevan, 2001; Balba et al., 2002; Urum et al., 2003). The ability to isolate high numbers of certain oil degrading microorganisms from oil-polluted environment is commonly taken as evidence that these microorganisms are the active degraders of that environment (Okerentugba and Ezeronye, 2003). The relevance of bacterial isolates in bioremediation of hydrocarbon contaminated systems especially in Nigeria is continually been investigated with the hope of stocking organisms that are useful for the bioremediation of crude oil polluted environments (Okoh et al., 2001; Okoh, 2003; Ogbeifun et al., 2004; Lu et al., 2000; Holt et al., 1994; Colle et al., 1996). In this study, we report the potential of a candidate bacterium-Proteus vulgaris SR-1in the biodegradation of Bonny light crude oil, diesel and kerosene.

\section{MATERIALS AND METHODS}

Microorganism, identification and maintenance: The hydrocarbon degrading bacterium strain used in this study were isolated from our previous study (Olajide et al., 2009) from newly killed fish samples collected close to the point of spill in the Niger Delta region in Nigeria. The purified bacterium strain was characterized for Gram reaction, cell morphology (Olajide et al., 2009) and biochemical/enzymatic analysis. The bacterium strain was grown in nutrient broth culture medium with a $2 \%(\mathrm{v} / \mathrm{v})$ inoculum and incubated $37^{\circ} \mathrm{C}$ with shaking at $125 \mathrm{rpm}$ (Lab-line No 3590) and regenerated twice before use in the manipulations. The regenerated strain was maintained on nutrient Broth agar (Merck) slants at $4^{\circ} \mathrm{C}$ and subcultured every three months or when necessary.

Inoculum was prepared by growing cells at $37^{\circ} \mathrm{C}$ for $24 \mathrm{~h}$ in Nutrient Broth and stirred in a rotary shaker at $120 \mathrm{rpm}$. The composition of the mineral salt medium used in this study was described by Tuleva et al. (2002).

Chemical reagent and hydrocarbon substrates: The Bonny light crude oil, diesel and kerosene were obtained from the Nigerian National Petroleum Corporation (NNPC) Warri, Delta State, Nigeria and all other chemicals used for this study are of analytical grade from BDH Chemicals Ltd. Poole, England except otherwise stated.

Screening of hydrocarbon degrading bacterium: Fifty milliliter of the mineral salt medium was distributed in a sterile conical flask, $1 \%$ of each hydrocarbon was aseptically added and controls also set up. After sterilization, the bacteria isolate Proteus vulgaris was inoculated into the flasks. The flasks were incubated at $37^{\circ} \mathrm{C}$ on a rotary shaker (Labline No 3590), with shaking at $120 \mathrm{rpm}$ for one week. Oil degradation was monitored by measurement of turbidity at a wavelength of $540 \mathrm{~nm}$ using a spectrophotometer (NOVASPEC II, Pharmacia Biotech). The measurement was taken for one week period to allow appreciable monitoring of bacteria growth under experimental conditions alongside that of sterile control. The $\mathrm{pH}$, Total Viable Counts (TVC) of the culture fluids were determined at time intervals as biodegradation indices (Rahman et al., 2002; Emtiazi and Shakarami, 2004).

Biodegradation of hydrocarbons by pure culture: A $50 \mathrm{~mL}$ of cooled sterilized mineral salts medium was dispensed into several sterilized $100 \mathrm{~mL}$ conical flasks and $0.5 \mathrm{~mL}$ of each sterilized hydrocarbon added to make the usual $1 \% \mathrm{w} / \mathrm{v}$ oil. To each of the flasks, a pure culture of isolate Proteus vulgaris already grown in nutrient broth and standardized to constant mass was added at about $1.0 \mathrm{~mL}$ of culture to a flask to maintain uniformity as much as possible. The flasks were incubated on rotatory shaker with shaking at $120 \mathrm{rpm}$ for one week at room temperature. After incubation, the level of used hydrocarbon degradation was determined using the gravimetric analysis (Chang, 1998; Marquez-Rocha et al., 2001). The percentage of hydrocarbon remaining was calculated compared to the control.

The effect of hydrocarbon degradation on $\mathrm{pH}$ : To study the effect of $\mathrm{pH}$ on hydrocarbon degradation, the $\mathrm{pH}$ of the medium was adjusted to the desired $\mathrm{pH}$ by adding either $0.1 \mathrm{M} \mathrm{HCl}$ or $0.2 \mathrm{M} \mathrm{NaOH}$ using glass electrodes. Following inoculation, the flasks were incubated on shaker at $150 \mathrm{rpm}$ for 3 days. The emulsification capacity of the culture broth free of cells was also determined (Yakimov et al., 1995).

Investigation of different salt concentrations effect on hydrocarbon degradation: The effect of salinity on hydrocarbon degradation was determined by adding different concentrations $(0.0-2 \%)$ of $\mathrm{NaCl}$ to 
the minimal salts medium. The mixtures were incubated at $37^{\circ} \mathrm{C}$ on shaker at $150 \mathrm{rpm}$ for 3 days (Prommachan et al., 2001). The emulsification capacity of the culture broth free of cells was also determined.

Plasmid DNA detection procedure: The presence of plasmid DNA in Proteus vulgaris SR-1 was done in accordance with the description of Kado and Liu (1981). Cells were grown in $3 \mathrm{~mL}$ of LB broth overnight at $37^{\circ} \mathrm{C}$ to an optical density at $600 \mathrm{~nm}$ of 0.8 and pelleted by centrifugation $\left(5,700 \mathrm{rpm}, 4^{\circ} \mathrm{C}\right.$, for $\left.7 \mathrm{~min}\right)$. The cell pellet was thoroughly resuspended in $1 \mathrm{~mL}$ of $\mathrm{TE}$ buffer (40 mM Tris-acetate and $2 \mathrm{mM}$ sodium EDTA). The Tris was adjusted to $\mathrm{pH} 7.9$ with glacial acetic acid. The cells were lysed by adding $2 \mathrm{~mL}$ of lysing solution (3\% SDS and $50 \mathrm{mM}$ Tris ( $\mathrm{pH}$ 12.6). The solution was adjusted to $\mathrm{pH} 12.6$ by adding $1.6 \mathrm{~mL}$ of $2 \mathrm{~N} \mathrm{NaOH}$, which was mixed by brief agitation. The solution was heated at $50-65^{\circ} \mathrm{C}$ for $20 \mathrm{~min}$ in a water bath and 2 volumes of phenol-chloroform solution (1:1 vol/vol) were added. The solution was emulsified by shaking briefly and the emulsion was broken by centrifugation $\left(6,000 \mathrm{rpm}, 15 \mathrm{~min}, 4^{\circ} \mathrm{C}\right)$. Avoiding the precipitate at the interface, the upper aqueous phase was transferred to Eppendorf micro centrifuge tubes. Samples were withdrawn directly for electrophoresis immediately or stored at $4^{\circ} \mathrm{C}$ until tested. As plasmid DNA samples contain RNA, $1 \mu \mathrm{L}$ of RNase was added to each $35 \mu \mathrm{L}$ of sample, mixed and incubated for $5 \mathrm{~min}$ at $37^{\circ} \mathrm{C}$ prior to gel loading. This was followed by addition of $7 \mu \mathrm{L}$ of loading dye. Plasmid DNA was analyzed by $1.0 \%$ agarose gel electrophoresis in TAE buffer $\mathrm{pH} 8.5$ for $30 \mathrm{~min}$. Lambda HindIII DNA molecular mass marker (23130-564 bp) was used as a standard for molecular mass determination. The gel was stained with

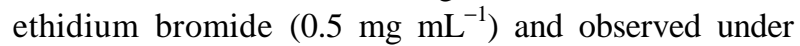
UV transilluminator for the presence of plasmid band. above, were digested an hour at $37{ }^{\circ} \mathrm{C}$ with ten units of various restriction enzymes and the fragments thus generated were fractionated by electrophoresis on $1.0 \%$ agarose gel as described.

\section{RESULTS}

Isolation and identification of bacterial strains: The test bacteria is a small, motile, Gram-negative, single rods, indole positive, oxidase negative, facultative anaerobe, while the results of biochemical and enzymatic assay correct identification rate without additional tests assay was $88.9 \%$ at the species level and $98.4 \%$ at the genus level. The overall rate of correct species identification was about $90 \%$ consistency index of Proteus vulgaris.
Hydrocarbon biodegradation: The utilization of hydrocarbons (Bonny light crude oil, Diesel and kerosene) as a substrates by isolate Proteus vulgaris SR-1 is evident by the increase in cell density. The results showed maximal increase in optical densities and total viable count concomitant with decrease in $\mathrm{pH}$ on fourth, fifth and eight day of reactions (Fig. 2-4). The maximum cell densities were $6.2 \log _{10}$ c.f.u $\mathrm{mL}^{-1}$ and over a $96-120 \mathrm{~h}$ of growth in $1 \%(\mathrm{v} / \mathrm{v})$ Bonny light crude oil and diesel respectively. The maximum cell density of $9.1 \log _{10}$ c.f.u mL $\mathrm{mL}^{-1}$ was obtained on $168 \mathrm{~h}$ during growth in the presence of $1 \%(\mathrm{v} / \mathrm{v})$ kerosene (Fig. 4).

Effect of Hydrocarbon Degradation on pH: The initial $\mathrm{pH}$ of medium was 7.0 in this experiment. Generally, a decreasing trend of $\mathrm{pH}$ was observed in the experimental flasks within the incubation period as growth increases in the presence of the three different hydrocarbons investigated (Fig. 1-3).

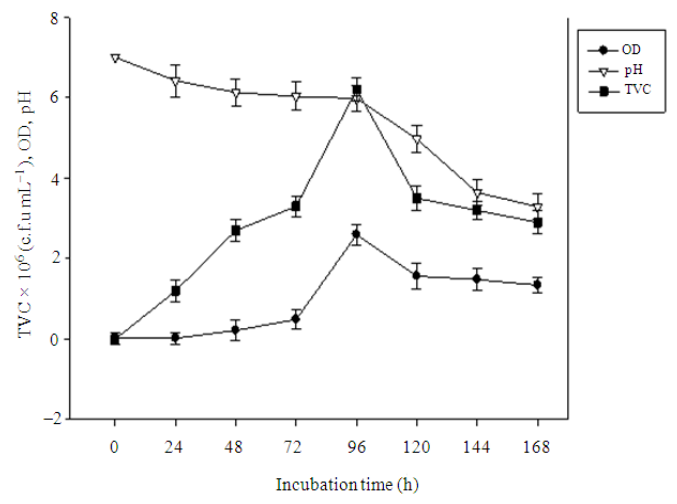

Fig. 1: Growth profile of Proteus species in mineral salt medium containing bonny light crude oil as sole carbon and energy source

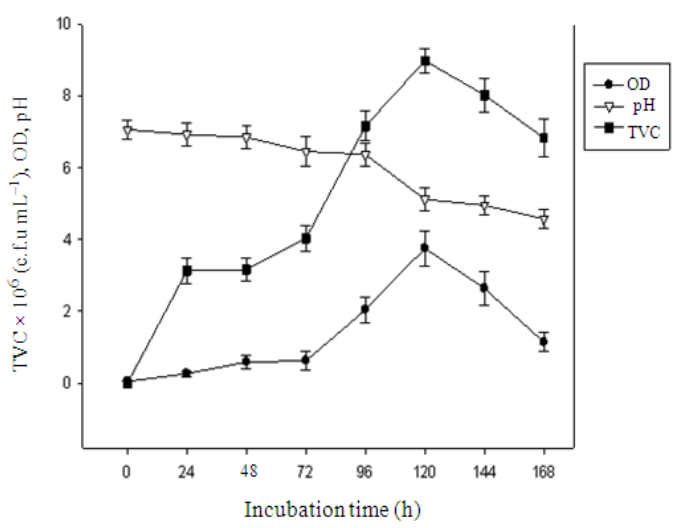

Fig. 2: Growth profile of Proteus species in mineral salt medium containing diesel oil as sole carbon and energy source 


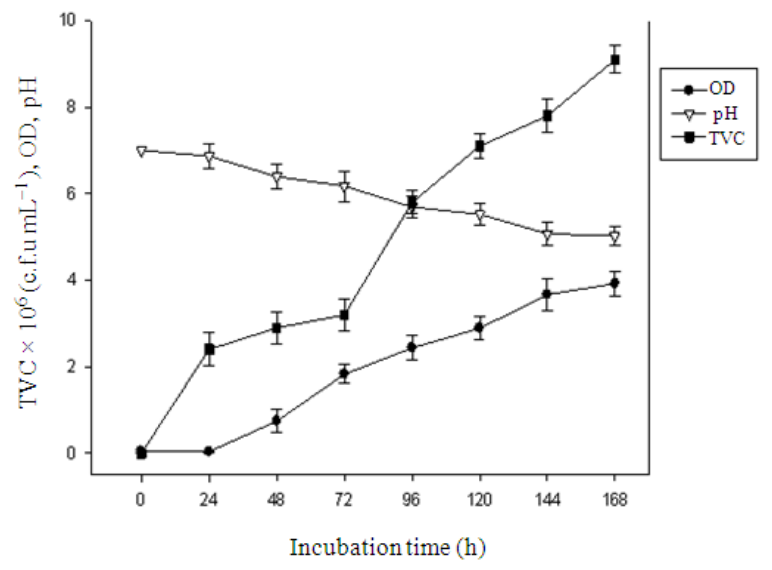

Fig. 3: Growth profile of Proteus species in mineral salt medium containing kerosene oil as sole carbon and energy source

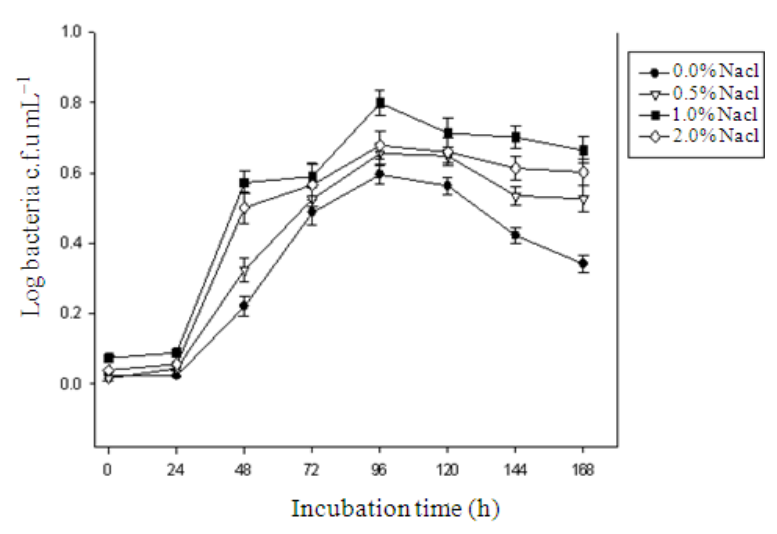

Fig. 4:Population growth of bacterial cells of Proteus vulgaris in crude oil medium containing different concentrations of $\mathrm{NaCl}(0.0-2.0 \%)$

Effect of salinity on hydrocarbon degradation: The effect of different $\mathrm{NaCl}$ concentrations (0-2\%) on hydrocarbons degradation from the crude oilcontaminated water was studied. The results showed that increasing $\mathrm{NaCl}$ concentration in water had decreasing effect on hydrocarbon degradation. The amount of oil degraded by Proteus vulgaris SR-1 strain increased initially to a maximum level at $1.0 \% \mathrm{w} / \mathrm{v}$ $\mathrm{NaCl}$, but thereafter decreased with increasing salt concentration and the patterns were similar for the three different test hydrocarbon substrates (Fig. 4-6). In all the various concentrations of $\mathrm{NaCl}$ used, salt concentrations did not affect the viable cell count during biodegradation. The results obtained were almost the same for the different hydrocarbons, though the number of total viable counts varied in each oil as shown in Fig. 4-6.

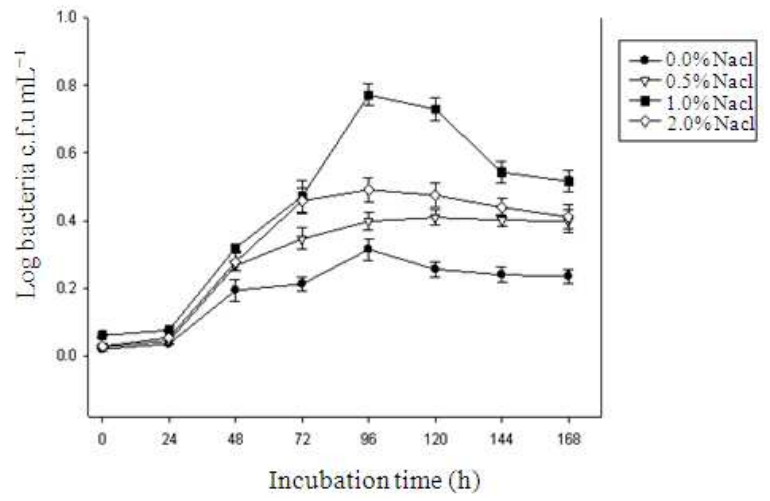

Fig. 5: Population growth of bacterial cells of Proteus vulgaris in kerosene oil medium containing different concentration of $\mathrm{NaCl}$ $(0.0-2.0 \%)$

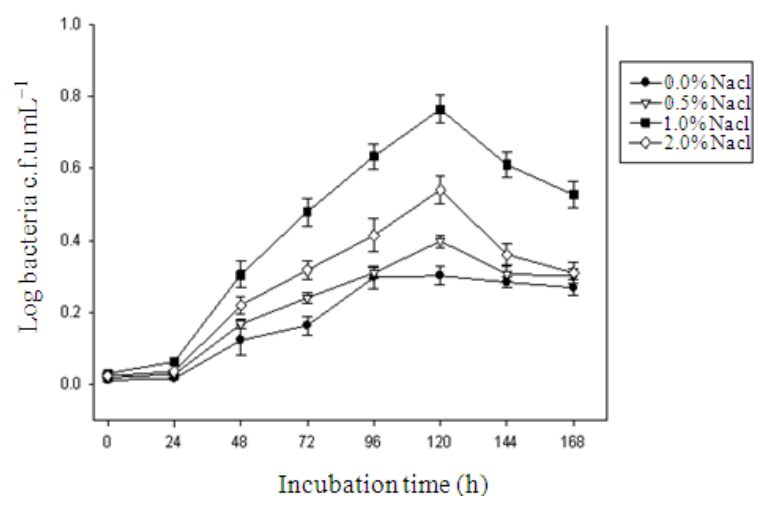

Fig. 6: Population growth of bacterial cells of Proteus vulgaris in diesel oil

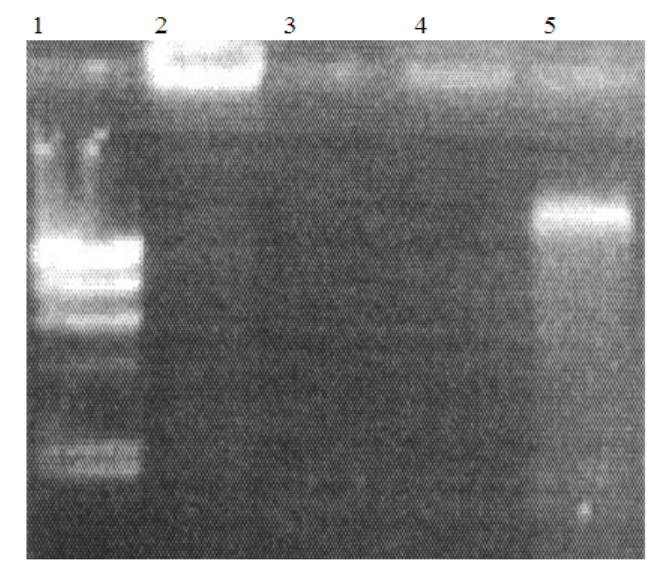

Fig. 7: Agarose gel electrophoresis of plasmid DNA from Proteus vulgaris (SR-1). Lane 1 is Hind111 marker and lane 5 contains the plasmid DNA from SR1 
Am. J. Applied Sci., 7 (7): 922-928, 2010

Table 1: Gravimetric analysis of oil degraded at $37^{\circ} \mathrm{C}$ after incubation for 5 days $^{-1}$

\begin{tabular}{llll}
\multicolumn{3}{c}{ incubation for 5 days } & Hydrocarbons \\
& & ------ \\
Media $(\% \mathrm{NaCl})$ & Bonny light crude oil & Kerosene & Diesel \\
\hline 0.0 & 73.98 & 72.73 & 67.41 \\
0.5 & 75.86 & 76.25 & 70.12 \\
1.0 & 78.10 & 79.92 & 73.80 \\
2.0 & 60.64 & 69.56 & 67.41 \\
\hline
\end{tabular}

Values are means of at least two replicates

Gravimetric analysis of oil degraded: The $\mathrm{NaCl}$ concentration for optimal growth was $1.0 \%(w / v)$ as observed in Table 1 The biodegradation of hydrocarbons were higher in $1.0 \% \mathrm{NaCl}$ and was 78.1 , 79.9 and $73.8 \%$ for Bonny light crude oil, kerosene and diesel respectively.

Evidence of plasmid DNA in isolate: Plasmid analysis revealed the presence of a plasmid of approximately $9.1 \mathrm{~kb}$ in the bacterial isolate Proteus vulgaris SR-1 (Fig. 7).

\section{DISCUSSION}

The isolate, Proteus vulgaris SR-1 was able to grow on crude petroleum as the sole source of carbon and energy when screened for hydrocarbon utilization. Interestingly, this same organism has been implicated in hydrocarbon degradation (Kayode-Isola et al., 2008).

The growth profiles of the bacterium were monitored by the optical densities, total viable count and the $\mathrm{pH}$ of the culture media. The results were shown in Fig. 1-3 and reflect that the isolates grew maximally on the three different hydrocarbon substrates when supplied as the sole source of carbon and energy. This technique was used in several studies to show the ability of bacteria utilizing crude oil (Emtiazi and Shakarami, 2004). In a similar investigation by Rahman et al. (2002) the total viable count method was used to confirm the potential of different kind of bacteria utilizing hydrocarbon. Thus bacterium growth reached the stationary phase and moved into the death phase in almost all the cases with the exception of kerosene. This is probably due to the chemistry of the hydrocarbon and the order of hydrocarbon degradation was; Kerosene>Bonny light crude oil $>$ diesel.

The utilization of the petroleum hydrocarbons as sole carbon and energy source by the isolate resulted in the growth with a resultant production of acid. This is probably as a result of chemical change of the crude oil hydrocarbons and production of by products and ability of isolated Proteus vulgaris to use crude oil and generate organic acids. Thus reducing the $\mathrm{pH}$ as has been reported elsewhere (Matthew, 2006). The initial $\mathrm{pH}$ of the medium was 7.0 and this decreased steadily as growth increases in the presence of the three different hydrocarbons as presented in Fig. 4-6. This finding is in agreement with the study of Sepahi et al. (2008) who reported that microbial degradation of hydrocarbons often leads to production of organic acids, thus the organic acids probably caused the reduction in $\mathrm{pH}$.

It is evident from this study that isolated Proteus vulgaris did not exhibit any lag phase in the culture media (Fig. 1-3). The result can be attributed to genetic makeup due to the constitutive expression of hydrocarbon catalyzing enzymes. This finding is in agreement with the study of Okerentugba and Ezeronye (2003) who reported that microorganisms growing on crude oil hydrocarbon did not exhibit any lag phase.

The tolerance of bacteria to salinity gradients could play a major role in its preferential use in the degradation of oil in marine environment. In this study, the amount of oil recovered from the sterile oil controls increased with increasing concentration of $\mathrm{NaCl}$. The quantity of oil degraded increased with increasing $\mathrm{NaCl}$ concentration in the experimental. The results obtained in (Table 1) showed that Proteus vulgaris did not tolerate high concentrations of $\mathrm{NaCl}$. It would therefore be unexpected that the isolate would thrive in marine system. Hence, it will be necessary to determine optimum salinity for every studied system.

The implication of plasmids in the degradation of petroleum hydrocarbons has also been a subject of investigation. Several methods have been reported for the isolation of plasmid DNA from Gram-negative bacteria (Davies and Normark, 1980; Anderson and McKay, 1983; Owen and Hernandez, 1990; Mottaleb et al., 2003). The application of these methods failed to demonstrate plasmids in Proteus vulgaris. The most satisfactory being the procedures described by Kado and Liu (1981). By this procedure, it was possible to identify one plasmid of molecular weight $9.1 \mathrm{~kb}$ from Proteus vulgaris (Fig. 7). SDS-curing of the isolates leads to complete loss of plasmid and hydrocarbon degradation activity.

\section{CONCLUSION}

The results of this study showed that Proteus vulgaris is a highly adapted bacterium with great potential to biodegrade hydrocarbons and the genes responsible for hydrocarbons biodegradation could be located on the $(9.1 \mathrm{~kb})$ plasmid it harbors. 


\section{ACKNOWLEDGEMENT}

I am grateful to Tel Aviv University and Prof. David Gutnick, of the Department of Molecular Microbiology and Biotechnology, Tel Aviv University, Israel, for the use of their equipment in carrying out the molecular aspect of this study.

\section{REFERENCES}

Anderson, D.G. and L.L. Mckay, 1983. Simple and rapid method for isolating large plasmid DNA from Lactic streptococci. Applied Environ. Microbiol., 46: 549-552. PMID: 6416164

Balba, M.T., Y. Al-Shayji, N. Al-Awadhi and A. Yateem, 2002. Isolation and characterization of biosurfactant producing bacteria from oilcontaminated soil. Soil Sediment Contam., 11: 41-55. DOI: 10.1080/20025891106682

Barathi, S. and N. Vasudevan, 2001. Utilization of petroleum hydrocarbons by Pseudomonas fluorescens isolated from petroleum contaminated soil. Environ. Intl., 26: 413-416. DOI: 10.1016/S01604120(01)00021-6

Chang, R., 1998. Chemistry. 6th Edn., McGraw-Hill Companies, Inc., pp: 962-963.

Colle, J.G., A.G. Fraser and B.P.S. Marmion, 1996. A Practical Medical Microbiology. Churchill Livingstone, New York, pp: 425.

Davies, J.K. and S. Normark, 1980. A relationship between plasmid structure, structural lability and sensitivity to site-specific endonucleases in Neisseria gonorrhoeae. Mol. Gen. Genet. MGG., 177: 251-260. DOI: 10.1007/BF00267436

Emtiazi, G. and H. Shakarami, 2004. Utilization of petroleum hydrocarbons by Pseudomonas sp. and transformed Escherichia coli. Afr. J. Biotechnol., 4: 172-176.

http://www.academicjournals.org/AJB/abstracts/ab s2005/Feb/Emtiazi\%20et\%20al.htm

Fasasi, A.E., 2006. Millennium development goal (3): How to ensure environmental sustainability in Nigeria. IPAN News, 7: 7-9.

Head, I.M. and R.P. Swannell, 1999. Bioremediation of petroleum hydrocarbon contaminants in marine habitats. Curr. Opin. Biotechnol., 10: 234-239. DOI: 10.1016/S0958-1669(99)80041-X

Holt, J.G., N.R. Krieg, P.H.A. Sneath, J.T. Stanley and S.T. William, 1994. Bergey's Manual of Determinative Bacteriology. William and Wilkins, Baltimore, USA.

HRW., 1999. The Price of Oil. http://www.hrw.org/reports/1999/nigeria/index.htm Human Right Watch
Kado, C.I. and S.T. Liu, 1981. Rapid procedure for the detection and isolation of large and small plasmids. J. Bacteriol., 145: 1365-1373. PMID: 7009583

Kayode-Isola, T.M., K.I.T. Eniola, A.B. Olayemi and O.O. Igunnugbemi, 2008. Response of resident bacteria of a crude oil-polluted river to diesel oil. Am. Eurasian J. Agron., 1: 6-9. http://www.idosi.org/aeja/1(1)08/2

Lu, J.J., C.L. Perng, S.Y. Lee and C.C. Wan, 2000. Use of PCR with universal primers and restriction endonuclease digestions for detection and identification of common bacterial pathogens in cerebrospinal fluid. J. Clin. Microbiol., 38: 2076-2080. PMID: 10834956

Marquez-Rocha, F.J., V. Hernandez-Rodriguez and M.T. Lamela, 2001. Biodegradation of diesel oil in soil by a microbial consortium. Water Air Soil Pollut., 128: 313-320. DOI: 10.1023/A:1010392821353

Matthew, O., 2006. Hydrocarbon degrading potentials of bacteria isolated from a Nigerian bitumen (Tarsand) deposit. Nat. Sci., 4: 51-57. DOI: 10.1007/s10669-009-9239

Mottaleb, M.A., D.K. Sarma, S. Sultana, M.M. Husain, S.M.M. Alam and S.M. Salehuddin, 2003. Determination of normal saturated-and polycyclic aromatic hydrocarbons in the river water of Bangladesh by liquid-liquid extraction and gas chromatography. Bull. Korean Chem. Soc., 24: 99-105. http://newjournal.kcsnet.or.kr/main/j_search/j_dow nload.htm?code $=$ B030122

Odokuma, L.O. and A.A. Dickson, 2003a. Bioremediation of a crude oil polluted tropical rainforest soil. Global J. Environ. Sci., 2: 29-40. http://ajol.info/index.php/gjes/article/view/2403/0

Odokuma, L.O. and A.A. Dickson, 2003 b. Bioremediation of a crude oil polluted tropical mangrove environment. J. Applied Sci. Environ. Manage., 7: 23-29. http://ajol.info/index.php/jasem/article/view/17207

Ogbeifun, P.O., S.O. Ajisebutu and A.I. Okoh, 2004. Species diversity of culturable crude oil degrading bacteria and physicochemical qualities of a crude oil polluted river in Nigeria. Fresenius Environ. Bull. Germany, 13: 643-646. http://www.cababstractsplus.org/Abstracts/Abstract .aspx?AcNo=20043144015

Okerentugba, P.O. and O.U. Ezeronye, 2003. Petroleum degrading potentials of single and mixed microbial cultures isolated from rivers and refinery effluents in Nigeria. Afr. J. Biotechnol., 2: 288-292. 
Okoh, A.I., 2003. Biodegradation of bonny light crude oil in soil microcosm by some bacterial strains isolated from crude oil flow stations saver pits in Nigeria. Afr. J. Biotechnol., 2: 104-108. http://www.academicjournals.org/AJB/abstracts/ab stracts2003/Mayabstracts2003/Okoh.htm

Okoh, A.I., 2006. Biodegradation alternative in the cleanup of petroleum hydrocarbon pollutants. Biotech. Mol. Biol. Rev., 1: 38-50. http://www.academicjournals.org/BMBR

Okoh, A.I., S.O. Ajisebutu, G. Babalola and M.R. Trejo-Hernandez, 2001. Potential of Burkholderia cepacia RQ1 in the biodegradtion of heavy crude oil. Int. Microbiol., 14: 83-87.DOl 10.1007/s101230100018

Olajide, P.O., S.O. Ajisebutu, S.B. Williams and L.B. Ogbeifun, 2009. Fish kills and physiochemical qualities of a crude oil polluted River in Nigeria. Res. J. Fish. Hydrobiol., 4: 55-64. http://www.insipub.com/rjfh/2009/55-64

Owen, R.J. and J. Hernandez, 1990. Occurrence of plasmids in Campylobacter upsaliensis (catalase negative or weak group) from geographically diverse patients with gastroenteritis or bacteraemia. Eur. J. Epidemiol., 6: 111-117. PMID: 2361534

Prommachan, O., H. Kittikun and F. Kawai, 2001. Production of biosurfactant from Bacillus MUV4. Proceeding of the Annual Meeting of the Thai Society for Biotechnology, Bio Thailand, From Research to Market, Bangkok, Thailand.

Rahman, K.S.M., J Thahira-Rahman, P. Lakshmanaperumalsamy and I.M. Banat, 2002. Towards efficient crude oil degradation by a mixed bacteria consortium. Bioresour. Technol., 85: 257-261. DOI: 10.1016/S0960-8524(02)00119-0
Sepahi, A.A., G.I. Dejban, M. Emami and A.M. Nakhoda, 2008. Isolation and characterization of crude oil degrading Bacillus spp. Iran J. Environ. Health Sci. Eng., 5: 149-154. http://www.bioline.org.br/request?se08027

Urum, K., T. Pekdemir and M. Gopur, 2003. Optimum conditions for washing of crude oil-contaminated soil with biosurfactant solutions. Process safety and environmental protection. Trans. Inst. Chem. Eng., 81: 203-209. DOI: 10.1205/095758203765639906

Trindade, P.V.O., L.G. Sobral, A.C.L. Rizzo, S.G.F. Leite and A.U. Soriano, 2005. Bioremediation of a weathered and a recently oilcontaminated soils from Brazil: A comparison study. Chemosphere, 58: 515-522. DOI: 10.1016/j.chemosphere.2004.09.021

Tuleva, B.K., G.R. Ivanov and N.E. Christova, 2002. Rhamnolipid production by a new Pseudomonas putida strain. Z. Naturforsch., 57: 356-360. PMID: 12064740

Yakimov, M.M., K.N. Timmis, V. Wray and H.L. Fredrickson, 1995. Characterization of a new lipopeptide surfactant produced by thermotolerant and halotolerant subsurface Bacillus licheniformis BAS50. Applied Environ. Microbiol., 61: 1706-1713. PMCID: PMC167432 